\title{
Bacterivory of a natural heterotrophic protozoan community exposed to different intensities of ultraviolet-B radiation
}

\author{
Khaled Chatila ${ }^{1}$, Serge Demers ${ }^{1, *}$, Behzad Mostajir $^{1}$, Michel Gosselin ${ }^{1}$, \\ Jean-Pierre Chanut ${ }^{1}$, Patrick Monfort ${ }^{2}$ \\ ${ }^{1}$ Groupe de Recherche en Environnement Côtier, Institut des Sciences de la Mer de Rimouski (ISMER), \\ Université du Québec à Rimouski, 310 Allée des Ursulines, Rimouski (Québec) G5L 3A1, Canada \\ ${ }^{2}$ Laboratoire d'Hydrobiologie Marine et Continentale, Unité mixte de Recherche 'Écosystèmes lagunaires', \\ Université Montpellier II, CNRS (UMR 5556), Case 093, 34095 Montpellier Cedex 05, France
}

\begin{abstract}
The effects of ultraviolet-B radiation (UVBR) on the bacterivory of a natural marine protozoan community were examined as part of a $7 \mathrm{~d}$ experiment designed to study the effects of different UVBR intensities on the summer planktonic assemblage of the lower St. Lawrence Estuary, Québec, Canada. The experiment was conducted in large containers (mesocosms) subjected to 1 of the following UVBR regimes: excluded UVBR (WUVB), natural UVBR (NUVB), and natural UVBR enhanced with either 2 lamps (LUVB) or 3 lamps (HUVB). Incubations with fluorescently labeled bacteria were conducted daily as a tool to understand the interaction between the potential bacterivores (heterotrophic ciliates and nanoflagellates) and bacteria within the studied system. UVBR intensities had no significant effects on the estimated clearance and ingestion rates (CR and IR, respectively) until Day 5 of the experiment. During the following $2 \mathrm{~d}$, characterized by low nutrient concentration, both CR and IR decreased with the increase of the daily UVBR (at 305 and $320 \mathrm{~nm}$ ) doses received. The maximum difference between treatments was observed on Day 7 , where both clearance and ingestion rate values in the NUVB, LUVB and HUVB treatments were significantly lower than the WUVB treatment. Our data suggest that over a $1 \mathrm{~d}$ period and under conditions of high nutrient concentrations, protozoan bacterivory is not affected by UVBR increases. When nutrient concentrations become low, bacterivores become more susceptible to damaging UVBR effects. We think that the deterioration of food quality, itself resulting from the synergistic action of nutrients and UVBR stresses, is responsible for the increased sensitivity of bacterivores to UVBR. UVBR-induced decreases in bacterivory would represent a considerable loss to the higher tropic levels that feed upon bacterivores.
\end{abstract}

KEY WORDS: Ultraviolet-B - Protozoa - Bacterivory - Bacterioplankton - Clearance rate - Ingestion rate · St. Lawrence Estuary

\section{INTRODUCTION}

The significant contribution of heterotrophic bacterioplankton and protozooplankton to the flux of organic matter in marine and freshwater ecosystems has now been established (Porter et al. 1985, Cole et al. 1988, Berninger et al. 1991, Azam 1998). Heterotrophic bacteria utilize dissolved organic matter (DOM) to build

\footnotetext{
- Corresponding author.

E-mail: serge_demers@uqar.uquebec.ca
}

up their cellular material (Ammerman et al. 1984, Moran \& Hodson 1990, Tranvik et al. 1993). The newly formed bacterial biomass is transferred to metazoans either directly, via predation by filter-feeding zooplankton (appendicularians; King et al. 1980, copepods; Pedrós-Alió \& Brock 1983, rotifers; Sanders et al. 1989, cladocerans; Pace et al. 1990, Vaqué \& Pace 1992) or indirectly, via protozoan bacterivory (mainly heterotrophic ciliates and nanoflagellates < $20 \mu \mathrm{m}$ : HCF) (Azam et al. 1983) and subsequent metazoan predation on protozoa. Because HNAN are generally considered 
the most efficient organisms in capturing bacteria (Fenchel 1982a,b, Bloem \& Bär-Gilissen 1989, Capriulo 1991), the indirect pathway is more likely to occur in both marine and freshwater environments (Güde 1986, Nagata 1988, Sanders et al. 1989, Carlough \& Meyer 1990, Wikner et al. 1990, Sanders et al. 1992). Thus, protozoan bacterivory, by regulating standing stocks, species composition and metabolic activity of the bacterial community, is believed to indirectly impact carbon flux dynamics (Taylor et al. 1985, Chrzanowski \& Simek 1990). In addition, since part of the DOM available to bacterial consumption is released by phytoplankton, either directly through normal leaking or aging (Linley et al. 1983, Obernosterer \& Herndl 1995) or indirectly through the grazing activity of herbivores (Jumars et al. 1989), bacterivory may be considered as a key process in recovering a considerable part of the primary production that would otherwise be lost to aquatic food webs (Ducklow et al. 1986). Given these significant roles, protozoan bacterivory has been a topic of keen interest to aquatic microbiologists during the last 2 decades.

Previous investigations have focused mainly on developing methods to measure protozoan bacterivory rates (Sherr \& Sherr 1983, Davis \& Sieburth 1984, Sherr et al. 1987, Bernard \& Rassoulzadegan 1990, Vrba et al. 1993, 1996) and on studying the importance of bacterivory in the modeling of carbon fluxes in specific water bodies (Weisse \& Scheffel-Möser 1991, Baranovic et al. 1993, Laurion et al. 1995, Stabell 1996, Becquevort 1997, Hadas et al. 1998). Studies addressing the effects of environmental stresses, such as ultraviolet-B radiation (UVBR; 280 to $320 \mathrm{~nm}$ ) on protozoan bacterivory, are scarce (Sommaruga et al. 1996, Wickham \& Carstens 1998).

In recent years, significant increases of UVBR fluxes reaching the earth's surface have been attributed to the increasing, but cyclic, depletion of the stratospheric ozone layer (Crutzen 1992). Despite the fact that ozone destruction due to reactions involving chlorofluorocarbons was believed to be stimulated by conditions specific to the region of Antarctica (Anderson et al. 1991), levels of stratospheric ozone measured during the past few years over the Arctic region have dropped, on a percentage basis, to values comparable to those recorded in Antarctica (Rex et al. 1997). Lower levels of ozone depletion have also been measured over more southerly regions including the United Kingdom (Pearce 1996) and midlatitude areas of Canada (Tarasick \& Fioletov 1997). These reported decreases stress the need to quantify the effects of UVBR on the aquatic ecosystems of the northern hemisphere.

Although representing a minor portion of the solar spectrum (less than $1 \%$ of total energy), UVBR is a highly active radiation that can penetrate to biologi- cally significant depths in lakes and oceans (Bergeron \& Vincent 1997). Depending upon the nature of the organism, the light regime, and the exposure time, UVBR effects on aquatic lives range from no consequence (Jokiel \& York 1984) to long-term depression of key physiological processes and/or acute physiological stress, to death via mutagenesis (Vincent \& Roy 1993). Indeed, it has been repeatedly shown that UVBR inhibits growth, photosynthesis, and cell division (Calkins \& Thordardottir 1980, Vosjan et al. 1990, Karentz et al. 1994) and alters the biochemical composition (Döhler 1992 and references cited therein) of primary producers. The few studies focusing on UVBR effects on heterotrophic organisms have shown that zooplankton (Zagarese et al. 1997), bacteria (Herndl et al. 1993, Müller-Niklas et al, 1995, Pakulski et al. 1998) and viruses (Suttle \& Chen 1992) are adversely affected by UVBR as well. For bacterivores, Sommaruga et al. (1996) reported a loss of motility and, consequently, a decrease of the bacterivory of the heterotrophic nanoflagellate Bodo saltans following its exposure to UVBR. Ochs (1997) described the grazing of an autotrophic picoplankton by 2 marine heterotrophic nanoflagellates exposed to ultraviolet (UV) light mainly enhanced at $354 \mathrm{~nm}$ (ultraviolet-A radiation; UVAR, 320 to $400 \mathrm{~nm}$ ). He reported an inverse relationship between prey mortality due to grazing and UV irradiance. This was attributed to a UV-induced decrease of both grazer survival and swimming capacity. In a recent study, grazing rates of the marine heterotrophic nanoflagellate Paraphysomonas bandaiensis upon 2 strains of the cyanobacteria Synechococcus spp. were found to be reduced upon UVBR exposure (Ochs \& Eddy 1998).

Apart from being limited in number, previous research in the field of protozoan UVBR photobiology has drawn conclusions from short temporal-scale investigations that employed pure cultures of laboratory grown organisms (Sommaruga et al. 1996, Ochs 1997). Although these studies constitute a fundamental step in the comprehension of the mechanisms by which UVBR affects phagotrophic protozoa, such conclusions cannot be readily extended to natural aquatic environments without prior in situ investigations (Sommaruga et al. 1996, Ochs 1997). Evidence indicates that, in general, species isolated from aquatic habitats experiencing high levels of UVBR have higher tolerance to this radiation than those growing in UVBR shielded environments (Calkins \& Thordardottir 1980). Given the species-specific differences in the degree of tolerance to UVBR, selected experimental organisms may not reflect the response of a diversified community of protozoa. Yet, in this respect it is believed that one of the main long-term effects of UVBR on aquatic ecosystems could be a change in community composition (Both- 
well et al. 1993). In addition, physical factors prevailing in real systems (e.g. vertical mixing; Neale et al. 1998) can modulate the overall influence of UVBR on its inhabitants.

The purpose of the present work is to evaluate the impact of natural and artificially enhanced UVBR on the bacterivory of a natural assemblage of bacterivorous protozoans. To do this, a natural planktonic community comprised of organisms $<240 \mu \mathrm{m}$ was isolated in large containers (mesocosms) and exposed to different UVBR levels for 7 consecutive days. Abundances of both potential bacterivorous protozoans (HCF) and their prey (heterotrophic bacteria) were determined daily. Some tintinnids and other unidentified species were present in the experimental water but were excluded from further analysis because their concentrations remained very low and relatively constant during the experiment with no significant differences between treatments (Mostajir et al. unpubl. data). Surface incubations with fluorescently labeled bacteria were conducted in parallel as a tool to explain the interactions between bacteria and their grazers under the tested UVBR levels. Other variables related to biological activity (either directly, e.g. phytoplankton abundance, chlorophyll $a$, or indirectly, e.g. nutrient concentrations) were monitored throughout the experiment as well. The potential effects of UVBR on protozoan consumption of bacteria are discussed in a broad context of food web dynamics.

\section{MATERIALS AND METHODS}

Experimental protocol. A $7 \mathrm{~d}$ experiment (17 to 23 July 1996) was conducted to characterize the effects of different intensities of UVBR (280 to $320 \mathrm{~nm}$ ) on various characteristics of the natural summer planktonic community of the St. Lawrence Estuary. The investigation was carried out in four 3500 l capacity doublewalled tanks (Fig. 1). The tanks are located outdoors at the aquaculture station of the Université du Québec à Rimouski, situated on the south shore of the St. Lawrence Estuary (Pointe-au-Père, Québec, Canada: $48.30^{\circ} \mathrm{N}, 68.29^{\circ} \mathrm{W}$ ). The experimental setup and light. regimes have been described in detail in Belzile et al. (1998). Briefly, 2 polyethylene mesocosms (1500 l each) were fitted in each tank in order to create replicates of 4 experimental UVBR treatments (Fig. 1A). Water was pumped from ca 1 to $2 \mathrm{~m}$ depth at the pier of Maurice Lamontagne Institute (Mont-Joli, Québec, Canada: $48.36^{\circ} \mathrm{N}, 68.13^{\circ} \mathrm{W}$ ) and was distributed evenly among the experimental mesocosms following its gravity filtration through a $240 \mu \mathrm{m}$ Nitex ${ }^{*}$ screen. Water inside the mesocosms was continuously mixed using a pump (Little Giant ${ }^{\circledR}$, model 2-MD-HC) at a rate of $251 \mathrm{~min}^{-1}$, yielding 1 turnover of the entire mesocosm water every hour. During periods of rain, polyethylene screens were installed on top of the tanks. Water temperature in the mesocosms was maintained at in situ water temperature by circulating local estuary water through the inner cavity of the double-walled tanks. Water removed from the mesocosms while sampling was not replaced. However, water was introduced between the mesocosms and the tank walls after each sampling. This added water lifted the mesocosms, therefore keeping the water level in the mesocosm constant in relation to the top of the tanks (Fig. 1B). Each of the 4 tanks was exposed to one of the following UVBR treatments: UVBR excluded with a $0.13 \mathrm{~mm}$ Mylar ${ }^{(2)}$ sheet (WUVB), natural UVBR (NUVB) and natural UVBR
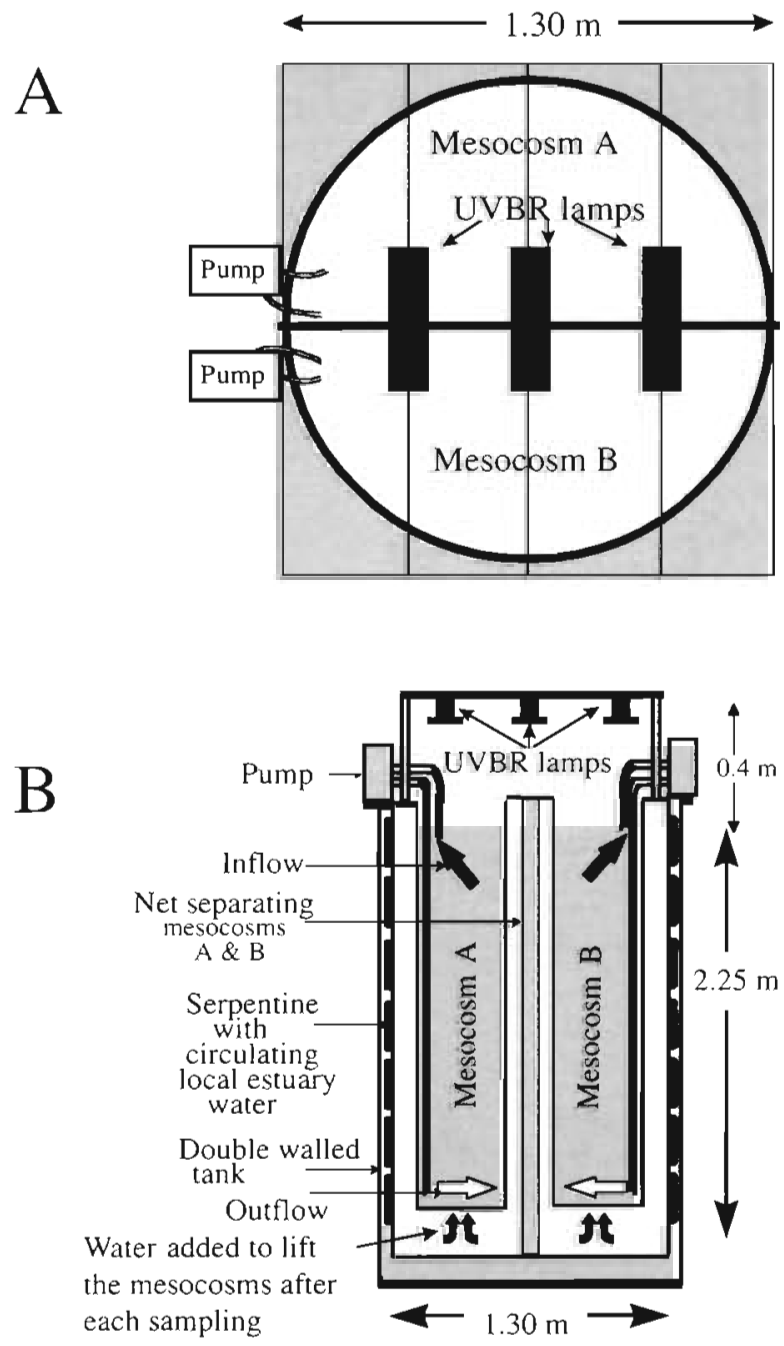

Fig. 1. Schematic view of an experimental tank in (A) top view showing the lamp configuration above the mesocosms and in (B) vertical view showing the fitted pair of mesocosms acting as replicates for a given treatment, the distance from the lamps to the water surface, the cooling system and the way mesocosms were lifted up following each sampling 
enhanced either with 2 lamps (LUVB) or with 3 lamps (HUVB). The lamps (emission peak at $312 \mathrm{~nm}$, preburned for $100 \mathrm{~h}$ ) were purchased from Spectronics Corporation (model XX15B). They were installed $0.4 \mathrm{~m}$ above the mesocosms' water surface (Fig. 1B) and were turned on from 09:00 to $17: 30 \mathrm{~h}$ each day. In order to attenuate wavelengths not encountered in nature but emitted by the lamps (ultraviolet-C radiation: UVCR, 250 to $280 \mathrm{~nm}$ ), the lamps were filtered with aged (1 h at $1 \mathrm{~cm}$ from the lamps) $0.13 \mathrm{~mm}$ cellulose acetate sheets (Cadillac Plastics) which were changed daily. In preliminary experiments, aged cellulose acetate sheets were found to be effective in the elimination of UVCR (Belzile et al. 1998). To ensure the same shading conditions in all treatments, 3 dummies (wooden cutouts with dimensions similar to the UVBR lamps) were installed over the NUVB mesocosms and a dummy was added to the lamps over the LUVB mesocosms. No dummies were installed over the WUVB mesocosms because the Mylar ${ }^{\otimes}$ sheet already somewhat reduced UVAR (320 to $400 \mathrm{~nm}$ ) and photosynthetically active radiation (PAR, 400 to $700 \mathrm{~nm}$ ). For 7 consecutive days, various parameters (e.g. temperature, incident irradiance, nutrients, chlorophyll a [chl a] and different organism abundances) were measured at least once per day (09:00 h). In relation to the present study, the following measurements were accomplished.

Physical variables. The natural incident intensities of UVBR, UVAR, and PAR were measured every $10 \mathrm{~min}$ using an IL 1700 radiometer (International Light Inc.) equipped with broadband, flat sensors designed for UVBR (SUD240/SPS300 filter/W diffuser), UVAR (SUD033/UVA filter/W diffuser) and PAR (SUD033/PAR filter/QNDS1/W diffuser) that provided a cosine-corrected irradiance. Peak wavelengths were at 275,365 , and $556 \mathrm{rm}$ for the UVBR, UVAR, and PAR sensors, respectively. A PUV-500 underwater radiometer (Biospherical Instruments) provided measurements of cosine-corrected downwelling irradiance at 305 , 320,340 , and $380 \mathrm{~nm}$. wavelengths (full bandwidth of 8 to $1.0 \mathrm{~nm}$ at half maximumj and a measurement of cosine-corrected downwelling PAR just below the water surface. To compensate for the underestimation caused by the PUV systems calibration method, the absolute irradiances at $305 \mathrm{~nm}$ were corrected using a factor of 2.6 (Kirk et al. 1994). The enhancement provided by the use of 2 or 3 lamps was calculated through the substraction of $305 \mathrm{~nm}$ irradiance in the NUVB treatment from the corresponding value under the LUVB and HUVB treatments, respectively. By repeating this on 4 consecutive days (20 to 23 July 1996), absolute enhancements by the lamps in the LUVB and HUVB treatments were found to be reasonably constant (for details see Belzile et al. 1998). An average absolute enhancement at $305 \mathrm{~nm}$ was calculated from the $4 \mathrm{~d}$ enhancement values in each UVBR enhanced treatment. Using the UVBR lamp spectra, the absolute enhancements at other wavelengths were deduced (Belzile et al. 1998) for every treatment. The integration of absolute enhancements at wavelengths from 280 to $320 \mathrm{~nm}$ yielded an average UVBR absolute enhancement in both the LUVB and HUVB treatments. These average UVBR enhancements were further transformed into doses provided by the lamps during the artificial UVBR exposure period (from 09:00 to 17:30 $\mathrm{h}$; $\Delta t=8.5 \mathrm{~h}$ ). An Optronic Laboratories OL 752 spectroradiometer that was available only during a part of the experiment was used to obtain the irradiance spectra just below the water surface of the different treatments.

In order to evaluate the magnitude and the biological importance of the experimental UVBR treatments, the relative increases in irradiance (irradiance in enhanced treatments divided by irradiance in natural treatment) were weighted with the DNA action spectrum of Setlow (1974) and compared to increases associated with ozone depletion in Antarctica. The lamps provided a constant UVBR intensity throughout their illumination period while the ambient UVBR was highly variable. This resulted in a considerably larger increase in the daily integrated UVBR dose in enhanced treatments than would be expected for projected decreases in stratospheric ozone. The constant lamp irradiance also resulted in unnatural UVBR:UVAR:PAR ratios in enhanced treatments, especially during the early and late hours of the artificial illumination period (data not shown).

Water temperature was measured every hour using type $\mathrm{J}$ thermocouples connected to a $21 \mathrm{X}$ datalogger (Campbell Scientific) and located between the 2 mesocosms in each tank.

Nutrients. Nitrate $\left(\mathrm{NO}_{3}\right)$ and ammonium $\left(\mathrm{NH}_{4}\right)$ concentrations were determined in the different mesocosms in the 09:00 $\mathrm{h}$ sample. To this end, $50 \mathrm{ml}$ aliquots were filtered through Whatman ${ }^{\otimes}$ GF/F (glass fiber) filters. A part of the filtrate was used immediately to analyze $\mathrm{NH}_{4}$ following the method of Solorzano (1969) described by Parsons et al. (1984). The remaining filtrate was then frozen at $-20^{\circ} \mathrm{C}$ for later determination of $\mathrm{NO}_{3}$ concentration using an Alpkem FS III Auto Analyzer

Chlorophyll a. Chl a was determined every $4 \mathrm{~h}$ during the first $4 \mathrm{~d}$ and 3 times a day $109: 00,13: 00$ and 17:00 h) during the final $3 \mathrm{~d}$ of the experiment according to the fluorometric method of Yentsch \& Menzel (1963) as described by Parsons et al. (1984). To this end, a $100 \mathrm{ml}$ sample was filtered in duplicate on $25 \mathrm{~mm}$ diameter Whatman $\mathrm{GF} / \mathrm{F}$ filters. Filters were frozen in liquid nitrogen and then stored at $-80^{\circ} \mathrm{C}$. Following a 24 h extraction of the filters in $90 \%$ ace- 
tone at $4^{\circ} \mathrm{C}, \mathrm{chl}$ a concentrations were determined with a 10-005R Turner Designs fluorometer. Readings were further corrected for phaeopigments.

Phytoplankton abundance. Immediately after the 09:00 h sampling, samples for phytoplankton abundance analysis $\left(2\right.$ mesocosm $\left.\mathrm{m}^{-1}\right)$ were stored at $4^{\circ} \mathrm{C}$ in the dark for a maximum of $2 \mathrm{~h}$. Cells belonging to either one of the 2 phytoplankton size classes (small: $<5 \mu \mathrm{m}$; large: 5 to $20 \mu \mathrm{m}$ ) were enumerated using a FACSORT Analyzer flow cytometer (Becton Dickinson) equipped with a $488 \mathrm{~nm}$ laser. The flow rate was adjusted to $12 \mu \mathrm{min}^{-1}$ and the acquisition time was at least 5 min. As an internal standard, $10 \mu \mathrm{m}$ beads (Immunocheck, Coulter) were added to samples. Cell Quest and Attractors software (Becton Dickinson) was used for data logging and analysis, respectively. Due to the relevance of $<5 \mu \mathrm{m}$ phytoplankton to the present study, their abundance over the entire experiment will be shown. Aspects of the abundance and taxonomy of the larger phytoplankton (5 to $20 \mu \mathrm{m}$ ) have been discussed in detail elsewhere (Villegas 1999).

Bacterial abundance. Samples for the determination of bacterial abundance were collected at 09:00 $\mathrm{h}$, fixed immediately with formaldehyde $(3.7 \%$ final concentration) and then stored at $4^{\circ} \mathrm{C}$. Sample processing started with applying DAPI stain (4', 6-diamidino-2 phenylindole, Sigma, $2.5 \mu \mathrm{g} \mathrm{ml}^{-1}$ final concentration) for $1 \mathrm{~h}$ at $4^{\circ} \mathrm{C}$ (Porter \& Feig 1980). Enumeration of cells was achieved using an ACR 1400SP flow cytometer (Bruker, Wissembourg) according to Monfort \& Baleux (1992).

Heterotrophic ciliates and nanoflagellates. In the present study, ciliates (15 to $35 \mu \mathrm{m}$ ) and heterotrophic nanoflagellates (HNF; 2 to $10 \mu \mathrm{m}$ ) were identified collectively as potential bacterivores ( $\mathrm{HCF}$ ). Their respective abundances were determined in the 09:00 h sample. For ciliates, a $100 \mathrm{ml}$ aliquot was preserved with acid Lugol (0.4\% final concentration), sedimented for $24 \mathrm{~h}$ and subsequently examined using a Zeiss ${ }^{(}$ inverted microscope. HNF were enumerated following the method of Booth (1993), which consisted of fixing a $25 \mathrm{ml}$ water sample with glutaraldehyde $(1.0 \%$ final concentration) for $10 \mathrm{~min}$ in the dark. Following this, the sample was filtered onto a $25 \mathrm{~mm}$ black Nuclepore polycarbonate membrane $(0.2 \mu \mathrm{m}$ pore size) using low vacuum (100 $\mathrm{mm} \mathrm{Hg}$ ). The filter was then mounted on a glass slide over a drop of Cargille type DF low-fluorescence immersion oil and a cover slip was placed on top. Enumeration was done using a Leitz ${ }^{\circledR}$ epifluorescence microscope.

Bacterivory incubations. Despite the numerous technical protocols available for estimating bacterivory of phagotrophic protists (reviewed by McManus \& Fuhrman 1988, Landry 1994), each of these techniques has its own shortcomings (Landry 1994). The use of a specific technique will largely depend, therefore, on the logistics of the experiment. All bacterivory estimates reported in the present study are based on the disappearance of fluorescently labeled bacteria (FLB) over 24 h incubations, as developed by Marrasé et al. (1992) and as later used by Laurion et al. (1995). The alteration of bacterivory rates resulting from increased prey concentrations and the egestion of bacterivore food vacuoles upon preservation (Landry 1994) are viewed as important limitations of this technique. In order to avoid such complications, the added prey concentration ranged from 25 to $30 \%$ of natural bacteria concentrations (Sherr \& Sherr 1993), and samples for FLB enumeration were preserved following the method recommended by Sherr et al. (1989) to minimize egestion problems. However, the major problem of selective bacterivory on labeled or non-labeled bacteria (Landry 1994) remains unresolved and all our estimates are, therefore, based on the assumption that bacterivores graze equally upon FLB and natural bacteria. The starting hypothesis for the bacterivory incubations in the present study stipulated that, upon UVBR exposure, the protozoan removal of FLB will decrease with an increase in the daily UVBR dose received in each treatment as a consequence of the bacterivores' susceptibility to UVBR.

FLB were prepared from the natural bacterial assemblage of the St. Lawrence Estuary according to the procedure of Sherr et al. (1987), concentrated and frozen as $5 \mathrm{ml}$ aliquots in $7 \mathrm{ml}$ plastic tubes about $10 \mathrm{~d}$ prior to the beginning of the study. Incubations were started every morning using the $5 \mathrm{ml}$ aliquot of FLB preparation that was thawed shortly before the start of the incubation and gently sonicated to reduce cell clumping. Five hundred $\mathrm{ml}$ aliquots of the 09:00 $\mathrm{h}$ samples were dispensed into Whirl-pak ${ }^{\oplus}$ bags, and a specific volume of the FLB preparation was added. This added volume was calculated so as to yield a final concentration of ca $2 \times 10^{5} \mathrm{FLB} \mathrm{ml}^{-1}$ sample. This concentration represented 25 to $30 \%$ of the abundance of natural bacteria, a good compromise between accuracy of measurements and the potential for altering the feeding activity of the natural bacterivorous protists (Sherr et al. 1989, Sherr \& Sherr 1993). Control incubations containing $0.2 \mu \mathrm{m}$ filtered, autoclaved seawater and FLB were included with the live incubations in order to investigate losses of FLB that were not related to grazing activity. All Whirl-pak ${ }^{\circledR}$ bags (1 bag meso$\operatorname{cosm}^{-1}$, i.e. 2 treatment ${ }^{-1}$ ) were incubated on the surface of the mesocosms. Two $15 \mathrm{ml}$ subsamples were drawn from each Whirl-pak ${ }^{*}$, one immediately after the FLB addition $(0 \mathrm{~h})$ and another after ' $t$ ' hours (24 h), transferred into a $50 \mathrm{ml}$ Falcon ${ }^{\circ}$ tube and preserved with alkaline Lugol solution ( $0.5 \%$ final concentration) and borate buffered formaldehyde ( $3 \%$ final concen- 
tration), and then stored in the dark at $4^{\circ} \mathrm{C}$. FLB abundances were determined by epifluorescence microscopy (Leitz ${ }^{\boxplus}$ ) using $10 \mathrm{ml}$ of the fixed subsamples that were filtered onto black Nuclepore filters $(0.2 \mu \mathrm{m}$ pore size). At least 400 FLB were counted on each slide. The bacterivory rate $(g)$, expressed in $\mathrm{h}^{-1}$, was estimated according to the equation reported by Marassé et al. (1992):

$$
g=\ln \left(F_{0} / F_{1}\right) t^{-1}
$$

where $F_{0}$ and $F_{\mathrm{t}}$ are the initial (at $0 \mathrm{~h}$ ) and final (at $24 \mathrm{~h}$ ) concentrations of FLB, respectively, and $t$ is the incubation time in hours $(24 \mathrm{~h})$.

The bacterivory rate, $g$, was divided by the abundance of potential bacterivores ( $\mathrm{HCF} \mathrm{nl}{ }^{-1}$ ) at the beginning of the incubation to obtain the clearance rate (CR: nl $\mathrm{HCF}^{-1} \mathrm{~h}^{-1}$, Fenchel 1984):

$$
\mathrm{CR}=g(\mathrm{HCF})^{-1}
$$

This expression of protozoan clearance rates has previously been used by other authors (e.g. Laurion et al. 1995).

Ingestion rates $\left(\mathrm{IR}_{i}\right.$ bacteria $\left.\mathrm{HCF}^{-1} \mathrm{~h}^{-1}\right)$ were calculated from clearance rate values as:

$$
\mathrm{IR}=\mathrm{CR} \times \text { bacterial concentration }
$$

The bacterial concentration used for calculations is the sum of the FLB and the natural bacteria concentrations at the beginning of each bacterivory experiment.

Statistical analysis. Prior to the statistical analysis of the data, the normality of distribution (test of conformity of Kolmogorov-Smirnov; Zar 1984) and the homogeneity of variance (test of Hartley; ibid) were tested. Because repeated measurements were made during several days on the same experimental units (mesocosms), analysis of variance (ANOVA) with repeated measures (following a multivariate ANOVA approach or profile analysis; Scheiner \& Gurevitch 1993) was used in order to test UVBR effect (between subject factor or mesocosms), time effect (or 'flatness' of the variable in relation to time) and UVBR treatment by time interaction (or 'parallelism' within subject factor or mesocosms). In addition, an ANOVA was performed to elucidate UVBR effect by testing mean differences between mesocosms for a given day (independently of time). The null hypothesis $\left(\mathrm{H}_{0}\right)$ stipulated that means of a measured variable remained equal under different treatments, e.g. variations in incident UVBR radiation have no effect on a given variable. When significant differences occurred, a post hoc test such as Dunnett's test, with NUVB treatment acting as the control group, was used. The probability values ( $p$ ) given hereafter are the results of these statistical tests.

\section{RESULTS}

\section{Physical variables}

Light measurements

Over the week-long duration of the present study, different meteorological conditions were encountered, resulting, therefore, in variable incident irradiances (Fig. 2). During the sunny Days 1, 2,6 and 7, the maximum recorded irradiances were $1.58 \mathrm{~W} \mathrm{~m}^{-2}, 35.81 \mathrm{~W} \mathrm{~m}^{-2}$, and $2080 \mu \mathrm{E} \mathrm{m}^{-2} \mathrm{~s}^{-1}$ for UVBR (Fig. 2A), UVAR (Fig. 2B) and PAR (Fig. 2C), respectively. Cloudy skies that persisted during Days 3, 4, and 5 reduced these maximums to $0.53 \mathrm{~W} \mathrm{~m}^{-2}, 14.31 \mathrm{~W} \mathrm{~m}^{-2}$, and $600 \mu \mathrm{E} \mathrm{m}^{-2} \mathrm{~s}^{-1}$, respectively. A fraction of incident irradiance (20 to $40 \%$ on sunny days and $37 \%$ on cloudy days) did not reach the mesocosms' water surface because of the shading induced by the tank wails and the UVBR lamps or the wooden lamp dummies. Details of shading effects on the
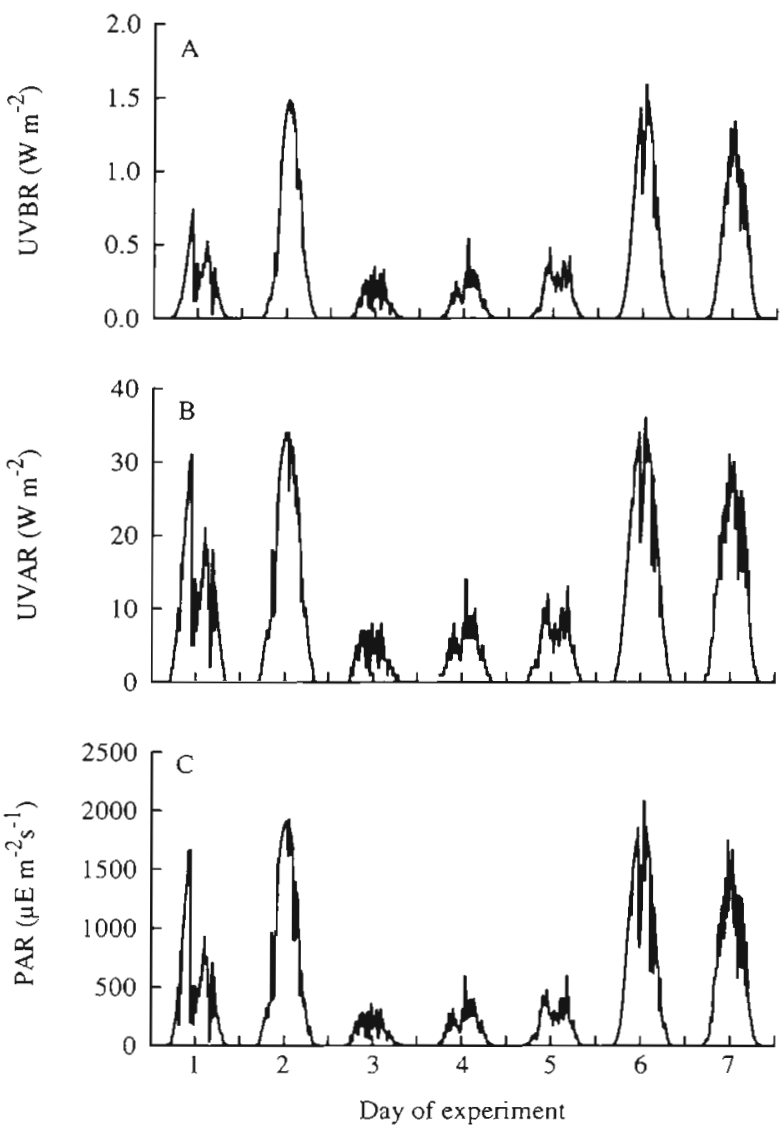

Fig. 2. Temporal variations of incident (A) UVBR (280 to $320 \mathrm{~nm}$ ), (B) UVAR (320 to $400 \mathrm{~nm}$ ), and (C) PAR (400 to $700 \mathrm{~nm}$ ) measured with an IL 1700 radiometer (International Light) at the study site (Pointe-au-Père, Québec, Canada: $48.6^{\circ} \mathrm{N}, 68.2^{\circ} \mathrm{W}$ ) from Day 1 ( $17 \mathrm{July}$ ) to Day 7 (23 July) of the experiment 
percentages of incident irradiances reaching the water surface are discussed in Belzile et al. (1998). Just below the water surface, the unweighted ultraviolet radiation spectra (280 to 400 ) conducted for the different treatments on a sunny day around noon (Fig. 3) indicated that most of the enhancement provided by the lamps was for the shorter wavelengths. Indeed, enhancement at the $305 \mathrm{~nm}$ just below the water surface ranged from 4.6 to $6.1 \mu \mathrm{W} \mathrm{cm}^{-2} \mathrm{~nm}^{-1}$ (average $5.62 \mu \mathrm{W} \mathrm{cm}^{-2} \mathrm{~nm}^{-1}$ ) and from 6.9 to $10.3 \mu \mathrm{W} \mathrm{cm} \mathrm{cm}^{-2} \mathrm{~nm}^{-1}$ (average $8.22 \mu \mathrm{W} \mathrm{cm} \mathrm{cm}^{-2}$ $\mathrm{nm}^{-1}$ ) in the LUVB and HUVB treatments, respectively. At $320 \mathrm{~nm}$, the increases in irradiance ranged from 2.33 to $3.98 \mu \mathrm{W} \mathrm{cm} \mathrm{nm}^{-1}$ (average $3.1 \mu \mathrm{W} \mathrm{cm} \mathrm{cm}^{-2} \mathrm{~nm}^{-1}$ ) and from 3.92 to $4.30 \mu \mathrm{W}$ $\mathrm{cm}^{-2} \mathrm{~nm}^{-1}$ (average $4.30 \mu \mathrm{W} \mathrm{cm} \mathrm{cm}^{-2}$ ) in the LUVB and HUVB treatments, respectively. Based on the local meteorological conditions and the $305 \mathrm{~nm}$ average enhancement values, the daily integrated doses at $305 \mathrm{~nm}$ ranged from 0.03 to $0.29 \mathrm{~kJ} \mathrm{~m}^{-2}, 1.75$ to $2.01 \mathrm{~kJ} \mathrm{~m}^{-2}$, and 2.55 to $2.80 \mathrm{~kJ} \mathrm{~m}^{-2}$ in the NUVB, LUVB and HUVB treatments, respectively (Table 1). At $320 \mathrm{~nm}$, the daily doses ranged from 0.49 to $2.70 \mathrm{~kJ} \mathrm{~m}^{-2}, 2.01$ to $4.22 \mathrm{~kJ} \mathrm{~m}^{-2}$, and 2.71 to $4.92 \mathrm{~kJ} \mathrm{~m}^{-2}$ in the NUVB, LUVB and HUVB treatments, respectively. Integration over the entire wave band from 280 to $320 \mathrm{~nm}$ yielded an average UVBR enhancement over ambient of 40.39 and $59.36 \mathrm{~kJ} \mathrm{~m}^{-2} \mathrm{~d}^{-1}$ at the water surface in the LUVB and HUVB treatments, respectively

Compared to UVBR levels measured on a sunny day around noon just below the water surface of the NUVB treatment, the unweighted UVBR irradiance was 1.10-

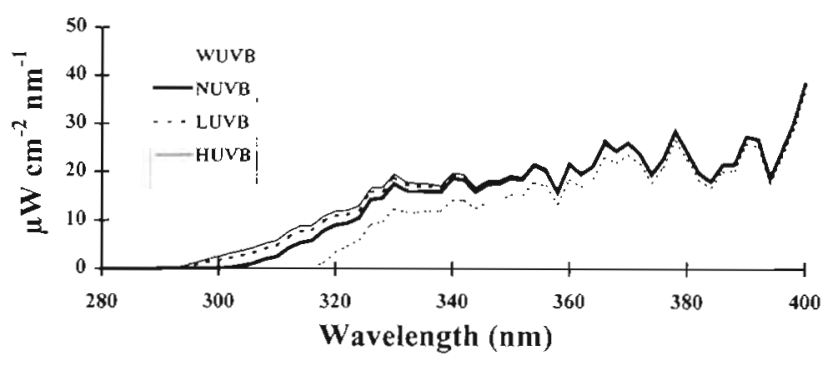

Fig. 3. Unweighted ultraviolet radiation intensities just below the water surface calculated for a sunny day at noon for different treatments. WUVB: excluded UVBR; NUVB: natural UVBR; LUVB and HUVB: natural UVBR enhanced with 2 and 3 lamps, respectively. It should be noted that the irradiance in the WUVB treatment was calculated by multiplying the irradiance in NUVB by the transmission spectra of the Mylar sheet as measured by a spectrophotometer. Contrary to the NUVB treatment, no dummy lamps were installed over the WUVB mesocosms to compensate for the $\cdot 10 \%$ reduction of UVAR and PAR (not measured) by the Mylar sheet. Consequently, $11 \%$ was added to the Mylar transmission spectra for wavelengths between 320 and $700 \mathrm{~nm}$ in order to obtain a transmission of 1 at $700 \mathrm{mn}$ (Mostajir et al. 1999b)
Table 1. Surface daily doses at 305 and $320 \mathrm{~nm}$ in the UVBR exposed mesocosms during the present study. For details on calculations, see Materials and methods'. NUVB: natural UVBR, LUVB and HUVB: natural UVBR enhanced with 2 and 3 lamps, respectively

\begin{tabular}{lcccccc} 
Date & \multicolumn{2}{c}{ NUVB $\left(\mathrm{kJ} \mathrm{m}^{-2} \mathrm{~d}^{-1}\right)$} & \multicolumn{2}{c}{ LUVB $\left(\mathrm{kJ} \mathrm{m}^{-2} \mathrm{~d}^{-1}\right)$} & \multicolumn{2}{c}{ HUVB $\left(\mathrm{kJ} \mathrm{m}^{-2} \mathrm{~d}^{-1}\right)$} \\
& 305 $\mathrm{nm}$ & $320 \mathrm{~nm}$ & $305 \mathrm{~nm}$ & $320 \mathrm{~nm}$ & $305 \mathrm{~nm}$ & $320 \mathrm{~nm}$ \\
\hline 17 July & 0.15 & 0.18 & 1.86 & 3.27 & 2.66 & 3.98 \\
18 July & 0.28 & 2.60 & 2.00 & 4.12 & 2.79 & 4.82 \\
19 July & 0.03 & 0.49 & 1.75 & 2.01 & 2.55 & 2.71 \\
20 July & 0.04 & 0.64 & 1.76 & 2.16 & 2.55 & 2.86 \\
21 July & 0.06 & 0.83 & 1.78 & 2.35 & 2.58 & 3.06 \\
22 July & 0.29 & 2.70 & 2.01 & 4.22 & 2.80 & 4.92 \\
23 July & 0.24 & 2.26 & 1.95 & 3.79 & 2.75 & 4.49
\end{tabular}

and 1.15-fold greater in the LUVB and HUVB treatments, respectively (Table 2). When weighted with the DNA action spectrum of Setlow (1974), these relative increases would be far more important than the weighted relative increase of UVBR associated with the ozone hole event over Antarctica (Table 2).

\section{Water temperature}

The circulation of local estuary water in the inner cavities of the double-walled tanks provided similar temperatures within all experimental mesocosms. During the $7 \mathrm{~d}$ of the experiment, temperature varied very little between the tanks. Recorded minimum and maximum values were 8.5 and $11.3^{\circ} \mathrm{C}$, respectively. Statistical analyses revealed that differences between treatments were not significant (Belzile et al. 1998).

\section{Nutrients}

\section{Nitrate $\left(\mathrm{NO}_{3}\right)$}

Concentration decreased from Day $1\left(10 \mu \mathrm{mol} \mathrm{I}^{-1}\right)$ to Day $3\left(<0.9 \mu \mathrm{mol} \mathrm{l}^{-1}\right)$ in all treatments (Fig. 4A). Start-

Table 2. Relative irradiance increases provided by the lamps just below the water surface on a sunny day around noon compared to relative increases associated with the ozone depletion event over Antarctica. Data for McMurdo (Antarctica) are from Cullen \& Neale (1997) and correspond to a decrease of ozone thickness from 350 to 175 Dobson Units. Relative increases were also weighted with the DNA action spectrum of Setlow (1974) normalized to 1 at $300 \mathrm{~nm}$

Incident solar irradiance LUVB HUVB at McMurdo

\begin{tabular}{lrrr}
\hline Unweighted ultraviolet & 1.06 & 1.10 & 1.15 \\
DNA action spectrum & 4.81 & 19.23 & 27.67
\end{tabular}



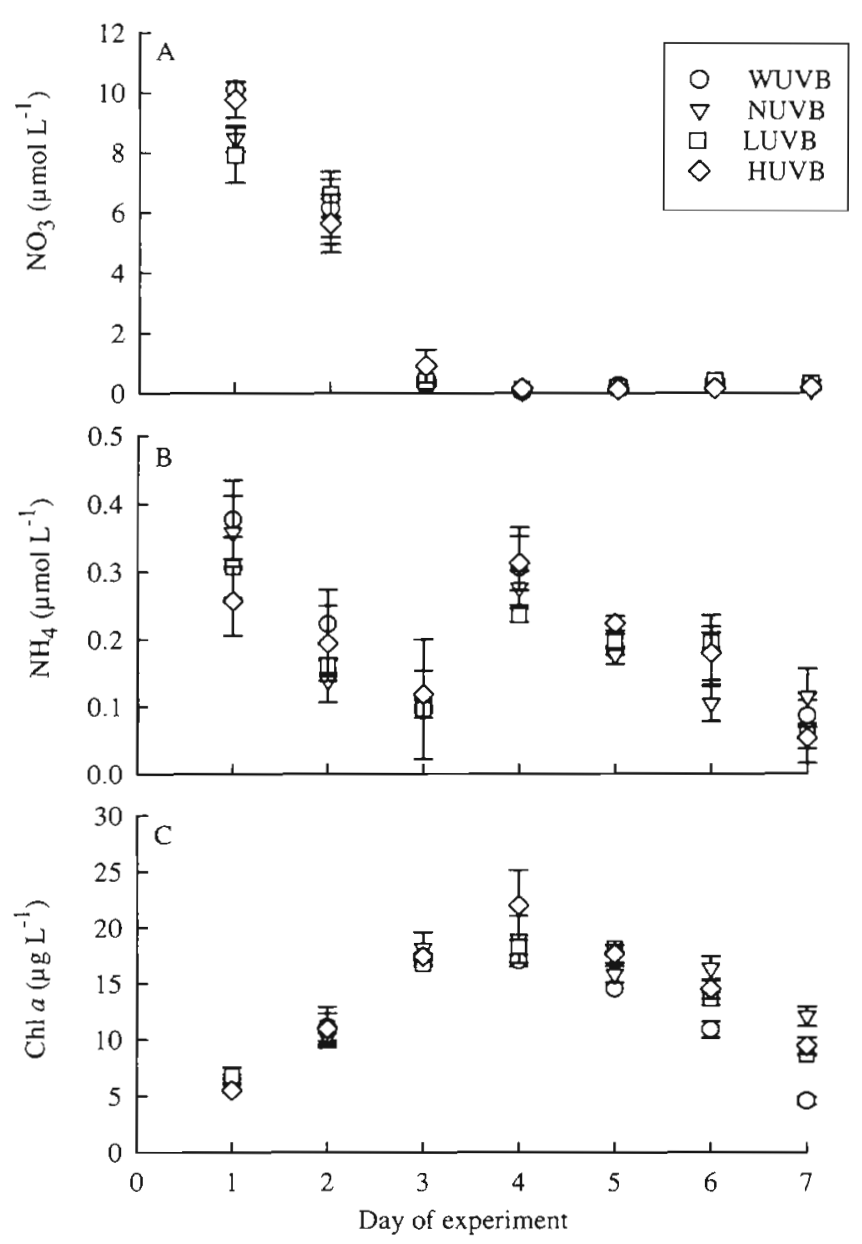

Fig. 4. Temporal variations in the concentrations of (A) nitrate, (B) ammonium, and (C) chlorophyl $a$ in the experimental treatments. Vertical bars represent the range of data from duplicate mesocosms exposed to a given UVBR treatment

ing from Day 4 and until the end of the experiment, all treatments were depleted in $\mathrm{NO}_{3}$. ANOVA with repeated measures showed no significant effects of UVBR treatments on $\mathrm{NO}_{3}$ concentration ( $p>0.05$ ).

\section{Ammonium $\left(\mathrm{NH}_{4}\right)$}

Throughout the experiment, $\mathrm{NH}_{4}$ concentrations varied similarly in the different treatments (test of parallelism; $p>0.05$ ) with no significant effect of treatment $(p>0.05)$. During the first $3 \mathrm{~d}$, concentrations decreased from values around $0.3 \mu \mathrm{mol} \mathrm{l}^{-1}$ (Fig. $4 \mathrm{~B}$ ) to ca $0.10 \mu \mathrm{mol} \mathrm{^{-1 }}$. On the fourth day, however, $\mathrm{NH}_{4}$ increased in all treatments yielding a marked peak. The peak value ranged from 0.2 to $0.3 \mu \mathrm{mol} \mathrm{I}^{-1}$ in the different treatments. Following this peak, values oscillated slightly but the general trend was a decrease. At the end of the experiment, values ranged from 0.04 to $0.12 \mathrm{nmol} \mathrm{l}^{-1}$ in the different treatments.

\section{Chlorophyll a}

Temporal variation of chl a concentrations in the different treatments is shown in Fig. 4C. Values increased in all treatments from Day 1 to Day 3 from ca $5 \mathrm{\mu g} \mathrm{l}^{-1}$ to ca $18 \mu \mathrm{g} \mathrm{l}^{-1}$ with no significant difference between treatments ( $p>0.1$ ). Following this, chl a concentrations leveled off in all treatments until Day 5. On Days 6 and 7, a decrease was observed in all treatments. The decrease was more pronounced in the WUVB treatment (down to $\sim 5 \mu \mathrm{g} \mathrm{l}^{-1}$ ) compared to the treatments including UVBR (down to $\sim 10 \mu \mathrm{g} \mathrm{l}^{-1}$ ). Statistical tests showed that UVBR exclusion did indeed result in a significant decrease of chl a concentration compared to NUVB ( $p<0.05)$.

\section{Abundance of phytoplankton $<5 \mu \mathrm{m}$}

At the beginning of the experiment, small phytoplankton $(<5 \mu \mathrm{m})$ abundance was around $9 \times 10^{3}$ cells $\mathrm{ml}^{-1}$. During the following $2 \mathrm{~d}$, abundances increased in all treatments to reach values around $17 \times 10^{3}$ cells $\mathrm{ml}^{-1}$ on Day 3 (Fig. 5A), with no significant difference between treatments ( $p>0.5$ ). From Day 4 to Day 6, abundances increased slightly in the UVBR enhanced treatments compared to the NUVB and WUVB treatments, where cell numbers remained quasi constant. On Day 7, abundances decreased significantly in the WUVB and NUVB treatments $(p<0.05)$ conversely to LUVB and HUVB treatments, which showed nonsignificant differences compared to their respective values on Day $6(\mathrm{p}>0.1)$. Relative to NUVB, abundances in the LUVB and HUVB treatments were almost 1.3 -fold greater. A parallel study revealed that almost $94 \%$ of the phytoplankton $<5 \mu \mathrm{m}$ were Prymnesiophyceae ranging in size from 2.7 to $4 \mu \mathrm{m}$ (Mostajir et al. 1999b).

\section{Abundance of bacteria}

Averaged for the 4 experimental treatments, the starting bacterial abundance was $0.9 \times 10^{6}$ cells $\mathrm{ml}^{-1}$. Afterwards, all treatments showed the following evolution (test for parallelism; $p<0.01$ ): an increase up to Day 3, a plateau from Day 3 to Day 4 then a decrease until Day 7 (Fig. 5B). With the exception of Day 3, where the exclusion of UVBR (WUVB treatment) significantly reduced the bacterial abundance in comparison to the NUVB treatment (Dunnett's post hoc test, $\mathrm{p}<0.01$ ), bacterial abundance was not significantly affected by UVBR during the first $4 \mathrm{~d}$ of the study. Significant difference between treatments ( $p<0.01$ ) was apparent during the following $3 \mathrm{~d}$, with 

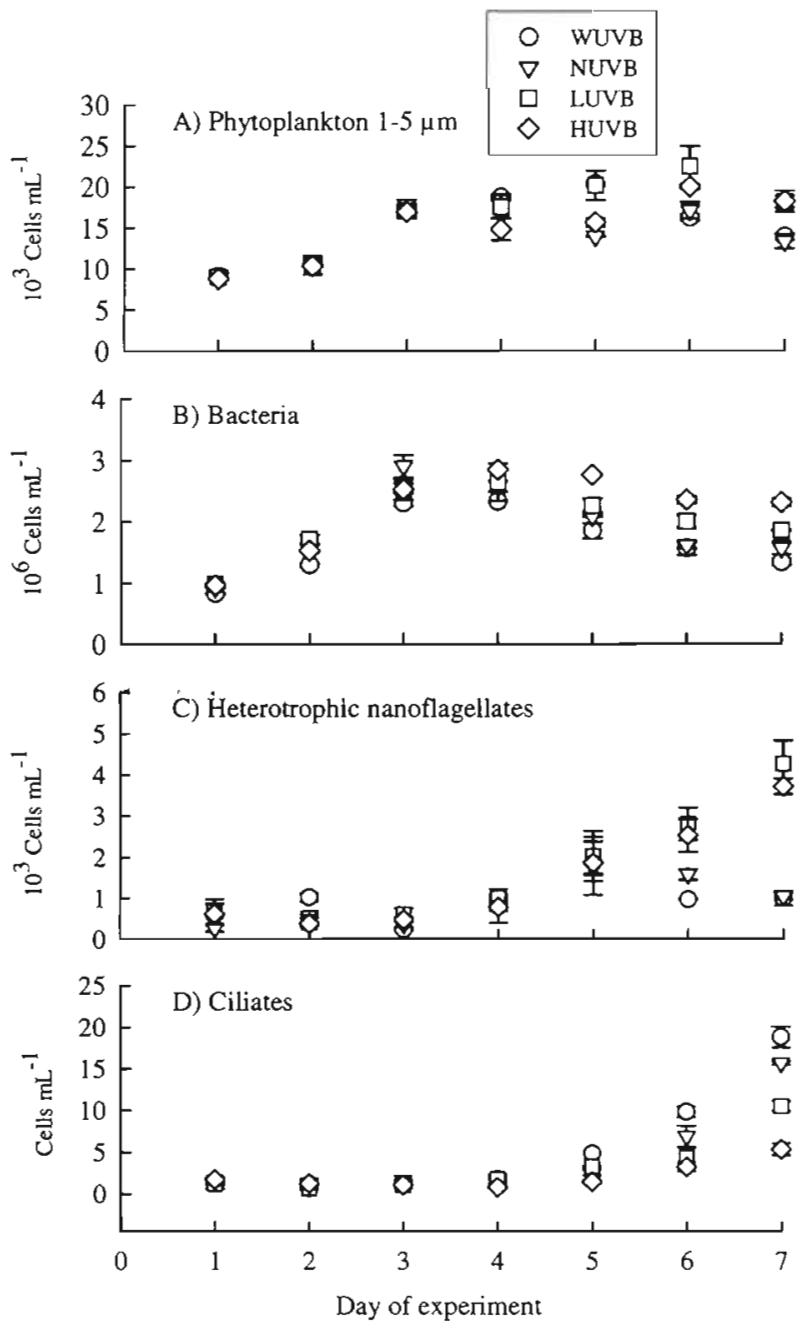

Fig. 5. Temporal variations of abundances of (A) small $(<5 \mu \mathrm{m})$ phytoplankton, (B) bacteria, (C) heterotrophic nanoflagellates, and (D) ciliates in the experimental treatments. Vertical bars represent the range of data from duplicate mesocosms exposed to a given UVBR treatment

the HUVB and WUVB treatments always showing the highest and the lowest cell abundance, respectively. As an average during this period, the abundance of bacteria in the HUVB, LUVB, and NUVB treatments were 73,39 and $17 \%$ higher than the WUVB treatment, respectively.

\section{Composition and dynamics of heterotrophic ciliates and nanoflagellates}

As mentioned earlier, the potential bacterivores (HCF) in the studied system included heterotrophic ciliates (15 to $35 \mu \mathrm{m}$, mainly oligotrichs, with the large majority being $<20 \mu \mathrm{m}$ ) and $\mathrm{HNF}$ ranging in size from 2 to $10 \mu \mathrm{m}$.
The HNF belonged mainly to the genera Bodo and Monosiga (Mostajir et al. 1999a). In general, HNF abundances increased in all treatments (test of flatness; $\mathrm{p}<0.005)$ from Day $1\left(\sim 0.53 \times 10^{3}\right.$ cells $\left.\mathrm{ml}^{-1}\right)$ to Day $5\left(\sim 1.8 \times 10^{3}\right.$ cells $\left.\mathrm{ml}^{-1}\right)$ with no significant difference $(p>0.1)$ between treatments (Fig. 5C). From Day 5 on, a significant increase in HNF abundance $(p<0.01)$ was observed in the LUVB and HUVB treatments, which showed almost the same counts $\left(\sim 4 \times 10^{3}\right.$ cells $\left.\mathrm{ml}^{-1}\right)$ on Day 7 . Regarding the NUVB and WUVB treatments, abundances declined to reach values around $1 \times 10^{3}$ cells $\mathrm{ml}^{-1}$ on Day 7 . On that day, significant difference between treatments $(p<0.05)$ was attributable to the LUVB and HUVB treatments, which were significantly different from the control NUVB (Dunnett's post hoc test; $\mathrm{p}<0.01$ ).

The ciliates were identified as Strobilidium spiralis, Strobilidium epacrum, Strombidium acutum, Lohmaniella oviformis, Uronema marinum, Laboea sp., and Askenasia sp. (Mostajir et al. 1999a). In all treatments, ciliate abundance was approximately 1.25 cells $\mathrm{ml}^{-1}$ until Day 4. From Day 4 on, increases were observed in all treatments. The magnitude of these increases differed from one treatment to the other following a pattern that suggests a negative effect of UVBR on ciliates. On Day 7, the greatest cell count was observed in the WUVB treatment ( 19 cells $\mathrm{ml}^{-1}$ ), followed by NUVB (16 cells $\mathrm{ml}^{-1}$ ), LUVB (10 cells $\left.\mathrm{ml}^{-1}\right)$ and finally HUVB (5 cells $\mathrm{ml}^{-1}$ ) (Fig. 5D). Thus, compared to the WUVB treatment, ciliate abundances were reduced by $\mathrm{ca} 17$, 44 and $72 \%$ in the NUVB, LUVB and HUVB treatments, respectively. Relative to the NUVB treatment, the decreases in ciliate abundances in the LUVB and HUVB treatments were 66 and $33 \%$, respectively. The differences between treatments were highly significant during the last $3 \mathrm{~d}(\mathrm{p}<0.001)$. Post hoc test results indicated that on Day 7, LUVB, HUVB and WUVB treatments were all significantly different from the control NUVB treatment $(p<0.05)$.

\section{Bacterivory incubations}

The variation in $g$ over the course of the present study is presented in Fig. 6A. From Day 1 through Day 5, $g$ varied very little in all treatments (average $0.067 \mathrm{~h}^{-1}$ ) with no significant effect of UVBR ( $p>0.05)$. During the final $2 \mathrm{~d}, g$ tended to increase in the WUVB treatment to reach a value of $0.09 \mathrm{~h}^{-1}$ on Day 7 . This value was found to be significantly higher than its corresponding one estimated in the control treatment NUVB (Dunnett's post hoc test; $p<0.05$ ). In respect to the NUVB, LUVB and HUVB treatments, $g$ values did not show any significant increase during the final $2 \mathrm{~d}$, either in relation to time (flatness test $; p>0.1$ ) or UVBR treatment $(p>0.1$ ) 

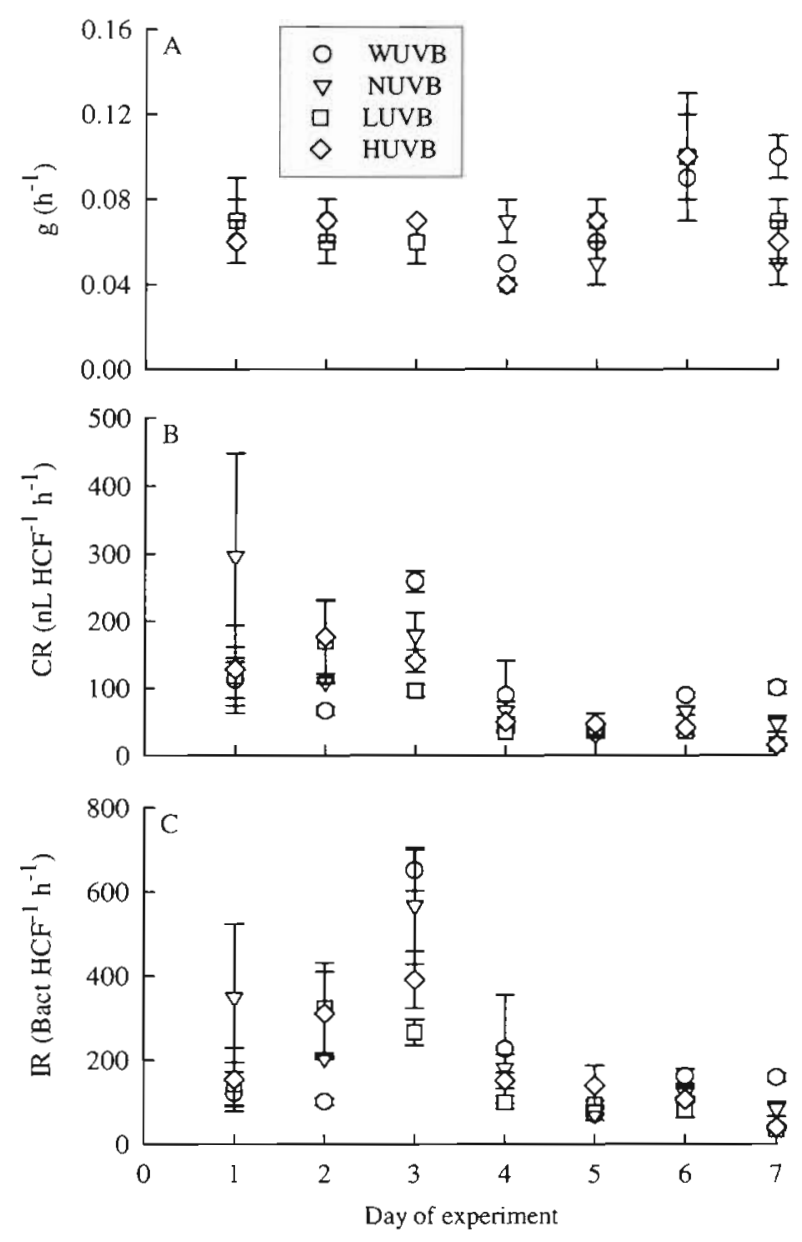

Fig. 6. Temporal variations in (A) bacterivory, (B) clearance rates, and $(C)$ ingestion rates $(g, C R$, and $I R$, respectively) from Day 1 to Day 7 in the experimental treatments. Vertical bars represent the range of data from duplicate mesocosms exposed to a given UVBR treatment

Over the whole period of the experiment, the average CR was $94.7 \mathrm{nl} \mathrm{HCF}{ }^{-1} \mathrm{~h}^{-1}$. Values ranged from 112 to 296 and from 16 to $100 \mathrm{nl} \mathrm{HCF}^{-1} \mathrm{~h}^{-1}$ on Days 1 and 7 , respectively. $C R$ tended to decrease towards the end of the present investigation (Fig. 6B). This decrease occurred mainly during the transition from Day 3 to Day 4 (test of flatness: $p<0.01$ ). From Day 4 on, CR estimates remained almost constant in all treatments except for the WUVB treatment, which tended to increase during the period from Day 5 to Day 6 and then remained constant on the next day. In respect to the UVBR treatment, the only significant difference between treatments was observed on Days 6 and 7 $(\mathrm{p}<0.01)$. Dunnett's post hoc test indicated that, indeed, the CR in the WUVB treatment was significantly different from that in the NUVB treatment $(p<0.05)$ on both final days. The enhanced UVBR treatments were not significantly different from NUVB during these same days $(p>0.1)$.
Variations of IR throughout the experiment are shown in Fig. 6C. IR values ranged from 121 to 348 and from 34 to 158 bacteria $\mathrm{HCF}^{-1} \mathrm{~h}^{-1}$ during Days 1 and 7 , respectively. There was, therefore, a tendency for IR to decrease in all treatments towards the end of the experiment. As an exception to this general pattern, IR increased significantly $(p<0.01)$ on Day 3 in all mesocosms. In respect to UVBR effect on IR, no significant differences could be detected between the different treatments during the first $6 \mathrm{~d}$ of the experiment. On Day 7, UVBR had a significant effect on IR values in the different treatments $(p<0.05)$. Dunnett's post hoc test, employing the NUVB treatment as a control, showed that the exclusion of UVBR had a significant effect on IR values $(p<0.05)$. Conversely, UVBR enhancement did not significantly affect IR values $(p>0.05)$.

In order to establish the link between UVBR exposure and bacterivory in the different treatments, the daily integrated doses at 305 (Fig. 7A) and $320 \mathrm{~nm}$
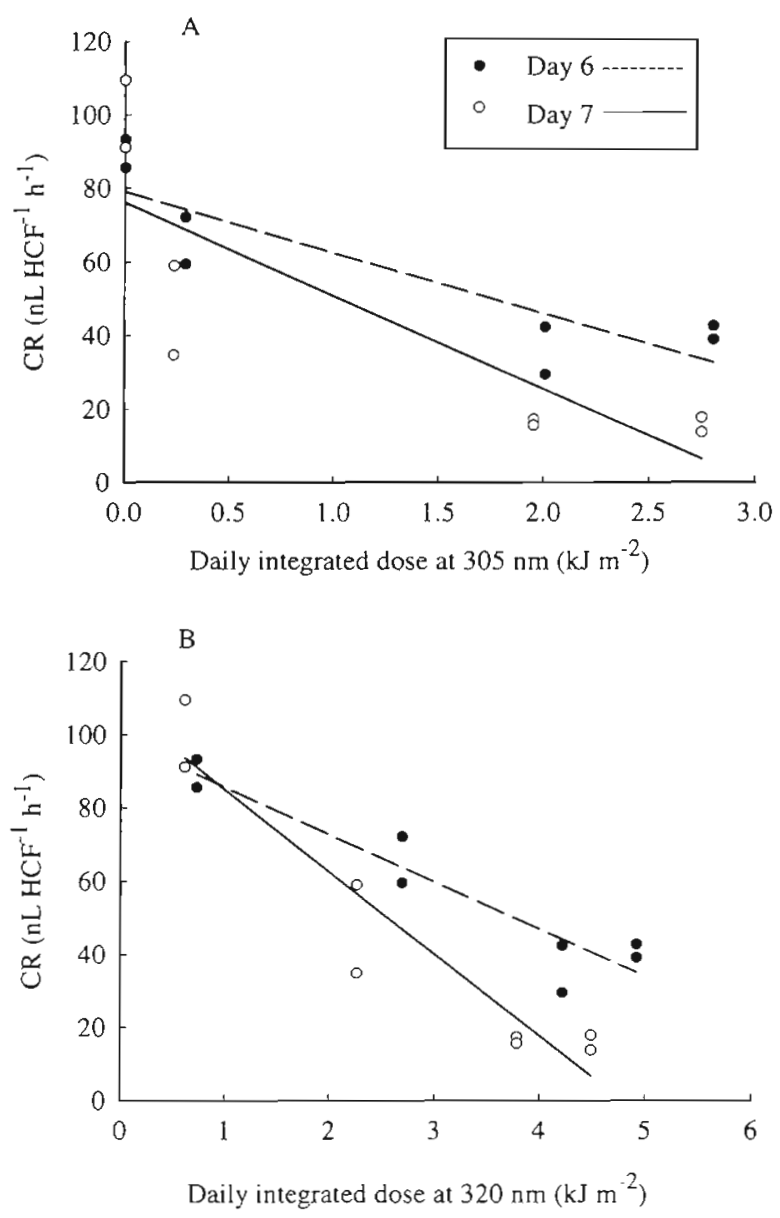

Fig. 7 Linear best fit curves illustrating the relation between the $\mathrm{CR}$ in the different mesocosms and the corresponding daily integrated doses at (A) $305 \mathrm{~nm}$ and (B) $320 \mathrm{~nm}$ on Days 6 and 7 of the experiment 
(Fig. 7B) were plotted against the respective $C R$ in the different experimental mesocosms on Days 6 and 7 . Indeed, $C R$ tended to decrease with the increase in UVBR dose received either at 305 or at $320 \mathrm{~nm}$. Pearson's correlation coefficient obtained for the different linear best fits were found to be significant ( $\mathrm{n}=8, \mathrm{r}_{0.05}$ $=0.707$ as critical value).

\section{DISCUSSION}

In the present study, an attempt was made to elucidate the effects of different UVBR intensities on the bacterivory of a natural protozoan community. This was conducted in the presence of protozoans' potential prey other than bacteria (small phytoplankton) and along a nutrient gradient that was set mainly by phytoplankton activity. It is, therefore, the first study to provide such information. The tight coupling and interaction which exist between the different components of microbial food webs determine the net response of a particular trophic level to UVBR (Wickham \& Carstens 1998).

Temperature has often been considered an important variable influencing bacterivory rates in aquatic systems (White et al. 1991, Marrasé et al. 1992, Peters 1994). In the present study, the cooling system surrounding the mesocosms allowed a good regulation of the temperature. Thus, the possibility of bacterivory being influenced by temperature difference between treatments was discarded.

During this investigation, the natural incident UVBR intensity attained a maximum of $1.58 \mathrm{~W} \mathrm{~m}^{-2}(2.8 \mu \mathrm{E}$ $\mathrm{m}^{-2} \mathrm{~s}^{-1}$ ). This value is ca 2 times greater than the value recorded in August 1993 on the southern shore of the lower St. Lawrence Estuary by Ferreyra (1995) and the one recorded at the same site in August 1994 by Sakka et al. (1997) (1 and $0.95 \mu \mathrm{E} \mathrm{m}^{-2} \mathrm{~s}^{-1}$, respectively). Conversely, it is much lower than the $10 \mu \mathrm{E} \mathrm{m} \mathrm{m}^{-2} \mathrm{~s}^{-1}$ UVBR value reported by Bothwell et al. (1993) for a site of similar latitude in July 1991 (South Thompson River, British Columbia, Canada; $\left.50^{\circ} 49^{\prime} \mathrm{N}\right)$. Relative to the NUVB treatment, the lamps used in the LUVB and HUVB treatments provided significant UVBR enhancements. When weighted with the DNA action spectrum of Setlow (1974), UVBR enhancement in the LUVB and HUVB treatments was much higher than the weighted increase in UVBR associated with the ozone hole in Antarctica (Cullen \& Neale 1997).

Despite the significant enhancements of UVBR above ambient levels in both LUVB and HUVB treatments, the studied protozoan population, whether in terms of abundance or grazing activity upon bacteria, did not show any UVBR related effect until Day 6. In addition, UVBR exclusion did not result in any enhancement for the measured protozoan variables. This is consistent. with the findings of Wickham \& Carstens (1998), who worked with a natural community and found that UVBR exclusion did not promote protozoan grazing or survival.

In the present study, the first bacterivory index calculated on the basis of FLB disappearance was the bacterivory rate $(\mathrm{g})$. Values for $g$ varied from 0.03 to $0.13 \mathrm{~h}^{-1}$, corresponding to removal rates in the range of 0.1 to $0.22 \times 10^{6} \mathrm{FLB} \mathrm{ml}^{-1} \mathrm{~d}^{-1}$. These estimates are above the maximum values reported for bacterivory in single protozoan cultures $\left(0.003\right.$ to $0.03 \mathrm{~h}^{-1}$; Sommaruga et al. 1996). They are, however, within the range previously reported for mixed protozoan communities $\left(0.04\right.$ to $\left.2 \times 10^{6} \mathrm{FLB} \mathrm{m}^{-1} \mathrm{~d}^{-1}\right)$ by Marrasé et al. (1992). The lack of well-defined differences in $g$ values in relation to the received UVBR may be partly due to the differences in potential bacterivore abundance between the experimental treatments. Therefore, in order to extract the influence of bacterivore abundance on the specific grazing activities of flagellates and ciliates on bacteria, the $C R$ were calculated. $C R$ provide information about the filtering activity, and thus about the feeding activity of potential bacterivores on a per cell basis. In the present study, the average calculated CR (95 $\mathrm{nl} \mathrm{HCF}^{-1} \mathrm{~h}^{-1}$ ) is in good agreement with the CR previously reported using disappearance type experiments, where rates range from 1.5 to $94 \mathrm{nl} \mathrm{HCF}^{-1} \mathrm{~h}^{-1}$ (Bjørnsen et al. 1988, Wikner et al. 1990). They also fell within the range of values (up to $100 \mathrm{nl} \mathrm{HCF}^{-1} \mathrm{~h}^{-1}$ ) previously reported for various aquatic systems (reviewed by Berninger et al. 1991). The ciliated protozoa may be responsible for the high CR measured during the present study. High CR values due to ciliate bacterivory were measured in 2 lakes located in the southeastern United States (up to $220 \mathrm{nl}$ ciliate ${ }^{-1} \mathrm{~h}^{-1}$ ) by Sanders et al. (1989) and in Lake Kinneret, Israel (405 nl ciliate ${ }^{-1}$ $\mathrm{h}^{-1}$ ), by Hadas et al. (1998). Research conducted in marine and estuarine systems confirmed that, by analogy to their lacustrine counterparts, marine and estuarine ciliates possess a strong affinity for bacterioplankton (Bird \& Kalff 1986, Rassoulzadegan et al. 1988, Sherr et al. 1989). Among ciliates, small oligotrichs are known to be voracious bacterivores (Christoffersen et al. 1990, Šimek et al. 1995). The ciliates within the studied protozoan community were mainly oligotrichs < $20 \mu m$ (Mostajir et al. 1999a), thus the high CR reported here may be due to their contribution to bacterivory. Furthermore, the ciliates' control on bacteria was suggested from abundance data on Days 6 and 7, where the highest bacterial counts coincided with the lowest counts of ciliates (HUVB and LUVB treatments). Conversely, the lowest bacterial counts were observed when ciliate abundances were high (NUVB and WUVB treatments). Due to the logistical constraints and the prolonged duration of bac- 
terivory incubations during the present study, bacterivore food vacuoles were not examined for their FLB contents. Therefore, it is impossible to determine the exact contribution of ciliates to bacterivory within our bacterivory data.

A number of interesting observations came out from $\mathrm{CR}$ data. First, as a common response for all treatments, the average $C R$ values during the first $3 \mathrm{~d}$ were substantially higher than those calculated for the subsequent $4 \mathrm{~d}$ (154 vs $\left.50 \mathrm{nl} \mathrm{HCF}^{-1} \mathrm{~h}^{-1}\right)$. It is possible that the increasing bacterial abundances observed during the first $3 \mathrm{~d}$ stimulated the bacterial removal by bacterivores. According to Choi \& Peters (1992), increases in bacterial abundances favor a higher protozoan removal of bacteria. The $\mathrm{CR}$ decline may have resulted from a shift in the protozoans' diet towards another prey. The best alternative prey for protozoans in the present study would be small phytoplankton (<5 $\mu \mathrm{m})$. This group showed a rapid increase in abuindance during the first $3 \mathrm{~d}$, then cell concentrations remained almost constant until Day 7 . During the latter period, abundances in the different treatments were in stark contrast to those of ciliates, supporting the assumption of ciliate control on small phytoplankton. It is, therefore, possible that small phytoplankton were available for protozoan grazing during the last $4 \mathrm{~d}$ of the experiment, relieving some of the pressure exerted by bacterivores on bacteria. In other words, protozoa fed mainly on bacteria when suitable size algal prey was scarce (Sherr et al. 1991). Behavioral flexibility in prey selection, due to the change in the concentration of potential food prey, is a well known feature of protozoa (Jürgens \& DeMott 1995, Laurion et al. 1995).

The second important observation in the CR data concerns the difference observed between the tested light regimes. The only significant difference between treatments was detected on Days 6 and 7 of the experiment, where the highest $C R$ were noted in the WUVB treatment followed by the NUVB, and finally by the LUVB and HUVB treatments. In addition, doseresponse curves obtained for $C R$ data on these 2 days showed that $C R$ decreased significantly $(\mathrm{p}<0.05)$ with the increase of the UVBR (at 305 and $320 \mathrm{~nm}$ ) daily doses. The different $C R$ among treatments were reflected in the bacterial abundance on these days, which showed an enhancement with the increase of UVBR intensity. In addition, the CR decrease with the increase of the received UVBR occurred concomitantly with the UVBR-induced decrease in ciliate abundances, reinforcing, therefore, our hypothesis of a bacterivory dominated by ciliates in the present investigation. Considering that the observed high abundance of HNF in UVBR enhanced treatments (LUVB and HUVB) represents a feedback mechanism pro- voked by the high susceptibility of HNF potential grazers (ciliates) to UVBR (Mostajir et al. 1999a), and that HNF are potential consumers of bacteria (Pace 1988), there is reason to hypothesize that HNF were not able to feed on bacteria in the presence of UVBR. UVBR effects on HNF may include a loss of motility (Sommaruga et al. 1996, Ochs 1997) that results from UVBR damage to flagellae (Häder \& Häder 1989). The tubilin sub-units of the flagella microtubules seem to be the main targets of UVBR (Häder \& Brodhun 1991).

The CR reported here are based on FLB disappearance over a $1 \mathrm{~d}$ incubation. One of the drawbacks of the FLB method is the possible protozoan selection of viable bacteria against FLB (Landry 1994). This implies that $C R$ based on FLB disappearance do not necessarily match natural bacteria removal. In order to verify that the patterns observed in $C R$ reflected the situation of natural bacteria as well, the CR were transformed into IR. Assuming a selective grazing favoring naturai bacteria, IR would not have shown the same tendency as CR. In the present study, the pattern observed in the calculated $\mathrm{CR}$ was not altered by their transformations into $I R$, indicating that protozoan selectivity towards natural prey, if present, was of negligible importance.

In support of our calculated bacterivory indices, the highest values reached by the $\mathrm{CR}$ and the IR data on Day 3 were reflected in the concentration of $\mathrm{NH}_{4}$ which, in turn, peaked the following day. $\mathrm{NH}_{4}$ is a by-product of bacterivory or of grazing, in general (Andersson et al. 1985, Berman et al. 1987). During this experiment, nitrate concentration decreased significantly during the first $3 \mathrm{~d}$, shifting the metabolism of phototrophic cells towards a regenerated production system based on $\mathrm{NH}_{4}$ (Fauchot 1998) in the following days. Therefore, changes in $\mathrm{NH}_{4}$ concentration during the final $4 \mathrm{~d}$ of the experiment will likely be related to the $\mathrm{NH}_{4}$ utilization/remineralization balance.

The question that arises now is why UVBR had a significant effect on protozoan bacterivory only during Days 6 and 7 of the study despite similar (Days 1 and 2 ), if not higher (cloudy days), UVBR enhancement on the previous days. The only interpretation that we can offer with the available data is that the nutritive quality of protozoan food (small phytoplankton and bacteria) acted in a synergistic way with the direct effects of UVBR on protozoans themselves. Firstly, there was a rapid phytoplankton-mediated exhaustion of nitrates during the first $3 \mathrm{~d}$ of the experiment. Nitrate depletion could have induced an increased phytoplankton susceptibility to UVBR (Cullen \& Lesser 1991), leading, therefore, to changes in their biochemical composition (Goes et al. 1994). Secondly, because phytoplankton is considered the ultimate source for bacterial growth substrates in closed mesocosm systems (Shiah \& Ducklow 1997), changes in the biochemical composition of 
phytoplankton (e.g. amino acids; Goes et al. 1995) may also affect that of bacteria (Herndl et al. 1993). With the deterioration of potential food quality, protozoan nutritive status is affected (Watanabe et al. 1983), leading most probably to an increased protozoan sensitivity to UVBR.

As suggested by our data, all components of an ecosystem will act jointly to determine the final outcome of UVBR on a given trophic level (Sommaruga et al. 1996, Wickham \& Carstens 1998, Mostajir et al. 1999a). Because bacteria depend mainly on phytoplankton release of DOM, the UVBR-induced alteration of phytoplankton biochemical processes (consequence of increased sensitivity to UVBR at low inorganic nutrient concentrations) may represent a considerable loss to bacterial essential growth substrates. Regarding protozoa, a diet consisting of bacteria that are deficient in essential nutritive requirements would probably render them more susceptible to the direct damaging effects of UVBR. However, because large zooplankton were removed during the present study, extrapolation of results to natural conditions cannot be straightforward. Due to the well-known trophic cascade effects (Güde 1988, Dolan \& Gallegos 1991), the presence of ciliate grazers may have largely modified the final outcome of the present study.

Acknowledgements. This work was supported by NSERC (Natural Sciences and Engineering Research Council of Canada), the Fonds FCAR (Fonds pour la Formation de Chercheurs et l'Aide à la Recherche du Québec) and FODAR (Fonds pour le Développement et l'Avancement de la Recherche, Université du Québec). International collaboration was made possible by a NATO collaborative research grant (no. CRG 95139) to S.D. and P.M. K.C. was financially supported by scholarships attributed by the Programme Canadien des Bourses de la Francophonie and the Groupe de Recherche en Environnement Cotier. We thank Claude Belzile who conducted light measurements, Dominic Bourget for ammonium analysis and Piedad $Z$. Villegas for counting the HNF. We also thank Guy Millette, Jacques Côté and Gilles Desmeules for their assistance in the setting of mesocosms and many summer students for their help during the experiment. The present work is a contribution to the research program of the Groupe de Recherche en Environnement Côtier. It is also a partial fulfillment of K.C.'s PhD thesis at the Université du Québec à Rimouski, Québec, Canada.

\section{LITERATURE CITED}

Ammerman JW, Fuhrman JA, Hagström $\AA$, Azam F (1984) Bacterioplankton growth in seawater. I. Growth kinetics and cellular characteristics. Mar Ecol Prog Ser 18:31-39

Anderson JG, Toohey DH, Brune WH (1991) Free radicals within the Antarctic vortex: the role of CFCs in Antarctic ozone loss. Science 251:39-46

Andersson A, Lee C, Azam F, Hagström $\AA$ (1985) Release of amino acids and inorganic nutrients by heterotrophic marine microflagellates. Mar Ecol Prog Ser 23:99-106
Azam F (1998) Microbial control of oceanic carbon flux: the plot thickens. Science 280:694-696

Azam F, Fenchel T, Field JG, Gray JS, Meyer-Reil LA, Thingstad $F$ (1983) The ecological role of water-column microbes in the sea. Mar Ecol Prog Ser 10:257-263

Baranovic A, Solic M, Vucetic T, Krstulovic N (1993) Temporal fluctuations of zooplankton and bacteria in the middle Adriatic Sea. Mar Ecol Prog Ser 92:65-75

Becquevort S (1997) Nanoprotozooplankton in the Atlantic sector of the Southern Ocean during the early spring: biomass and feeding activities. Deep-Sea Res II 44:355-373

Belzile C, Demers S, Lean DRS, Mostajir B, Roy S, de Mora S, Bird D, Gosselin M, Chanut JP, Levasseur M (1998) An experimental tool to study the effects of ultraviolet radiation on planktonic communities: a mesocosm approach Environ Technol 19:667-682

Bergeron M, Vincent WF (1997) Microbial food web responses to phosphorus supply and solar UV radiation in a subarctic lake. Mar Ecol Prog Ser 12:239-249

Berman T, Nawrocki M, Taylor GT, Karl DM (1987) Nutrient flux between bacteria, bacterivorous nanoplanktonic p̈rotists and algae. Mar Microb Food Webs 2:69-82

Bernard C, Rassoulzadegan F (1990) Bacteria or microflagellates as a major food source for marine ciliates: possible implications for the microzooplankton. Mar Ecol Prog Ser 64:147-155

Berninger UG, Caron DA, Sanders RW, Finlay BJ (1991) Heterotrophic flagellates of planktonic communities, their characteristics and methods of study. In: Patterson DJ, Larsen $J$ (eds) The biology of free-living heterotrophic flagellates. Clarendon Press, Oxford, p 39-56

Bird DM, Kalff J (1986) Bacterial grazing by planktonic lake algae. Science 231:493-495

Bjørnsen PK, Riemann B, Horsted SJ, Nielsen TG, Pock-Sten J (1988) Trophic interactions between heterotrophic nanoflagellates and bacterioplankton in manipulated seawater enclosures. Limnol Oceanogr 33:409-420

Bloem J, Bär-Gilissen MJB (1989) Bacterial activity and protozoan grazing potential in a stratified lake. Limnol Oceanogr 34:297-309

Booth BC (1993) Estimating cell concentration and biomass of autotrophic plankton using microscopy. In: Kemp PF, Sherr BF, Sherr EB, Cole JJ (eds) Handbook of methods in aquatic microbial ecology. Lewis Publishers, Boca Raton, FL, p 199-205

Bothwell ML, Sherbot D, Roberge AC, Daley RJ (1993) Influence of natural ultraviolet radiation on lotic periphytic diatom community growth, biomass accrual, and species composition: short-term versus long term effects. J Phycol 29:24-35

Calkins J, Thordardottir $T$ (1980) The ecological significance of solar UV radiation on aquatic organisms. Nature 283: $563-566$

Capriulo GM (1991) Community grazing in heterotrophic marine protista-session summary. In: Reid PC, Turley CM, Burkill PH (eds) Protozoa and their role in manine processes. NATO ASI Series. Springer Verlag, Berlin, p 205-218

Carlough LA, Meyer JL (1990) Rates of protozoan bacterivory in three habitats of a southeastern Blackwater River. J N Am Benthol Soc 9:45-53

Choi JW, Peters F (1992) Effects of temperature on two psychrophilic ecotypes of a heterotrophic nanoflagellate, Paraphysomonas imperforata. Appl Environ Microbiol 58: 593-599

Christoffersen K, Riemann B, Hansen LR, Klysner A, Sørensen $\mathrm{HB}$ (1990) Qualitative importance of the microbial 
loop and plankton community structure in a eutrophic lake during a bloom of cyanobacteria. Microb Ecol 20: $253-272$

Chrzanowski TH, Šimek K (1990) Prey-size selection by freshwater flagellated protozoa. Limnol Oceanogr 35 $1429-1436$

Cole JJ, Findlay S, Pace ML (1988) Bacterial production in fresh and saltwater ecosystems: a cross-system overview. Mar Ecol Prog Ser 42:1-10

Crutzen PJ (1992) Ultraviolet on the increase. Nature 356 $104-105$

Cullen JJ, Lesser MP (1991) Inhibition of photosynthesis by ultraviolet radiation as a function of dose and dosage rate: results for a marine diatom. Mar Biol 111:183-190

Cullen JJ, Neale PJ (1997) Biological weighing functions for describing the effects of ultraviolet radiation on aquatic systems. In: Häder DP (ed) Effects of ozone depletion on aquatic ecosystems. RG Landes, Georgetown, p 97-118

Davis PG, Sieburth JMcN (1984) Estuarine and oceanic microflagellate predation of actively growing bacteria: estimation by frequency of dividing-divided bacteria. Mar Ecol Prog Ser 19:237-246

Döhler $G$ (1992) Impact of UV-B radiation on uptake of ${ }^{15} \mathrm{~N}$-ammonia and ${ }^{15} \mathrm{~N}$-nitrate by phytoplankton of the Wadden Sea. Mar Biol 112:485-489

Dolan JR, Gallegos CL (1991) Trophic coupling of rotifers, microflagellates, and bacteria during fall months in the Rhode River estuary. Mar Ecol Prog Ser 77:147-156

Ducklow HW, Purdie DA, Williams PJLeB, Davies JM (1986) Bacterioplankton: a sink for carbon in a coastal marine plankton community. Science 232:865-867

Fauchot J (1998) Influence du rayonnement UV-B sur I'utilisation de l'azote par une communauté phytoplanctonique naturelle. MSc thesis, Université du Québec à Rimouski

Fenchel T (1982a) Ecology of heterotrophic microflagellates. I. Some important forms and their functional morphology Mar Ecol Prog Ser 8:211-223

Fenchel T (1982b) Ecology of heterotrophic microflagellates II. Bioenergetics and growth. Mar Ecol Prog Ser 8:224-231

Fenchel T (1984) Suspended marine bacteria as a food source In: Fasham MJR (ed) Flows of energy and materials in marine ecosystems. Plenum Press, New York, p 301-315

Ferreyra GA (1995) Effets du rayonnement ultraviolet sur le plancton des régions froides tempérées et polaires PhD thesis, Université du Québec à Rimouski

Goes JI, Handa N, Taguchi S, Hama T (1994) Effects of UV-B radiation on the fatty acid composition of the marine phytoplankter Tetraselmis sp.: relationship to cellular pigments. Mar Ecol Prog Ser 114:259-274

Goes JI, Handa N, Taguchi S, Hama T, Saito H (1995) Impact of UV radiation on the production patterns and composition of dissolved free and combined amino acids in marine phytoplankton. J Plankton Res 17:1337-1362

Güde $H$ (1986) Loss processes influencing growth of planktonic bacterial populations in Lake Constance. J Plankton Res 8:795-810

Güde H (1988) Direct and indirect influences of crustacean zooplankton on bacterioplankton in Lake Constance. Hydrobiologia 159:63-73

Hadas O, Malinsky-Rushansky N, Pinkas R, Cappenberg TE (1998) Grazing on autotrophic picoplankton by ciliates isolated from Lake Kinneret, Israel. J Plankton Res 20: $1435-1448$

Häder D, Häder M (1989) Effects of solar radiation on photoorientation, motility and pigmentation in a freshwater Cryptomonas. Bot Acta 102:236-240

Häder DP, Brodhun B (1991) Effects of ultraviolet radiation on the photoreceptor proteins and pigments in the paraflagellar body of the flagellate Euglena gracilis. J Plant Physiol 137:641-646

Herndl GJ, Müller-Niklas G, Frick J (1993) Major role of ultraviolet- $B$ in controlling bacterioplankton growth in the surface layer of the ocean. Nature 361:717-719

Jokiel PL, York RH (1984) Importance of ultraviolet radiation in photoinhibition of microalgal growth. Limnol Oceanogr 29:192-199

Jumars PA, Penry DL, Baross JA, Perry MJ, Frost BW (1989) Closing the microbial loop: dissolved carbon pathway to heterotrophic bacteria form incomplete ingestion, digestion and absorption in animals. Deep-Sea Res 36:483-495

Jürgens K, DeMott WR (1995) Behavioral flexibility in prey selection by bacterivorous nanoflagellates. Limnol Oceanogr 40:1503-1507

Karentz D, Bothwell ML, Coffin RB, Hanson A, Herndl GJ, Kilham SS, Lesser MP, Lindell M, Moeller RE, Morris DP, Neale PJ, Sanders RW, Weiler CS, Wetzel RG (1994) lmpact of UV-B radiation on pelagic freshwater ecosystems: report of working group on bacteria and phytoplankton. Arch Hydrobiol Beih Ergebn Limnol 43:31-69

King KR, Hoilibaugh JT, Azam F (1980) Predator-prey interactions between the larvacean Oikopleura dioica and bacterioplankton in enclosed water columns. Mar Biol 56: $49-57$

Kirk JTO, Hargreaves BR, Morris DP, Coffin RB, David B, Fredrickson D, Karentz D, Lean DRS, Lesser MP, Madronich S, Morrow JH, Nelson NB, Scully NM (1994) Measurements of UV-B radiation in two freshwater lakes: an instrument intercomparison. Arch Hydrobiol Beih Ergebn Limnol 43:71-99

Landry MR (1994) Methods and controls for measuring the grazing impact of planktonic protists. Mar Microb Food Webs 8:37-57

Laurion I, Demers S, Vézina AF (1995) The microbial food web associated with the ice algal assemblage: biomass and bacterivory of nanoflagellate protozoans in Resolute Passage (High Canadian Arctic). Mar Ecol Prog Ser 120:77-87

Linley EAS, Newell RC, Lucas MI (1983) Quantitative relationship between phytoplankton, bacteria and heterotrophic microflagellates in shelf waters. Mar Ecol Prog Ser $12.77-89$

Marrasé C, Lim EL, Caron DA (1992) Seasonal and daily changes in bacterivory in a coastal plankton community. Mar Ecol Prog Ser 82:281-289

McManus GB, Fuhrman JA (1988) Control of marine bacterioplankton populations: measurement and significance of grazing. Hydrobiologia 159:51-62

Monfort P, Baleux B (1992) Comparison of flow cytometry and epifluorescence microscopy for counting bacteria in aquatic ecosystems. Cytometry 13:188-192

Moran MA, Hodson RE (1990) Bacterial production on humic and nonhumic components of dissolved organic carbon. Limnol Oceanogr 35:1744-1756

Mostajir B, Demers S, deMora S, Belzile C, Chanut JP, Gosselin $M$, Roy $S$, Zulema Villegas $P$, Fauchot J, Bouchard J, Bird D, Monfort P, Levasseur M (1999a) Experimental test of the effect of ultraviolet- $B$ radiation in a planktonic community. Limnol Oceanogr 44:586-596

Mostajir B, Sime-Ngando T, Demers S, Belzile C, Roy S, Gosselin $M$, Chanut JP, de Mora S, Fauchot J, Vidussi F, Levasseur M (1999b) Ecological implications of changes in cell size and photosynthetic capacity of marine Prymnesiophyceae induced by ultraviolet-B radiation. Mar Ecol Prog Ser 187:89-100

Müller-Niklas G, Heissenberger A, Puškaric S, Herndl GJ 
(1995) Ultraviolet-B radiation and bacterial metabolism in coastal waters. Aquat Microb Ecol 9:111-116

Nagata T (1988) The microflagellate-picoplankton food linkage in the water column of Lake Biwa. Limnol Oceanogr 33:504-517

Neale PJ, Davis RF, Cullen JJ (1998) Interactive effects of ozone depletion and vertical mixing on photosynthesis of Antarctic phytoplankton. Nature 392:585-589

Obernosterer I, Herndl GJ (1995) Phytoplankton extracellular release and bacterial growth: dependence on the inorganic N:P ratio. Mar Ecol Prog Ser 116:247-257

Ochs CA (1997) Effects of UV radiation on grazing by two marine heterotrophic nanoflagellates on autotrophic picoplankton. J Plankton Res 19:1517-1536

Ochs CA, Eddy LP (1998) Effects of UV-A (320 to 399 nanometers) on grazing pressure of a marine heterotrophic nanoflagellate on strains of the unicellular cyanobacteria Synechoccus spp. Appl Environ Microbiol 64:287-293

Pace ML (1988) Bacterial mortality and the fate of bacterial production. Hydrobiologia 159:41-49

Pace ML, McManus GB, Findlay S (1990) Planktonic community structure determines the fate of bacterial production in a temperate lake. Limnol Oceanogr 35:795-808

Pakulski JD, Aas P, Jeffrey W, Lyons M, Von Waasenbergen L, Mitchell D, Coffin R (1998) Influence of light on bacterioplankton production and respiration in a subtropical coral reef. Aquat Microb Ecol 14:137-148

Parsons TR, Maita Y, Lalli CM (1984) A manual of chemical and biological methods for seawater analysis. Pergamon Press, Toronto

Pearce F (1996) Big freeze digs a deeper hole in ozone layer. New Sci 2021:7

Pedrós-Alió C, Brock TD (1983) The impact of zooplankton feeding on the epilimnetic bacteria of a eutrophic lake. Freshwat Biol 13:227-239

Peters F (1994) Prediction of planktonic protistan grazing rates. Limnol Oceanogr 39:195-206

Porter KG, Feig YS (1980) The use of DA.PI for identifying and counting aquatic microflora. Limnol Oceanogr 25:943-948

Porter KG, Sherr EB, Sherr BF, Pace M, Sanders RW (1985) Protozoa in planktonic food webs. J Protozool 32:409-415

Rassoulzadegan F, Laval-Pento M, Sheldon RW (1988) Partitioning of the food ration of marine ciliates between picoand nanoplankton. Hydrobiologia 159:75-88

Rex M, Harris NRP, Wenger J (1997) Prolonged stratospheric ozone loss in the 1995-96 Arctic winter. Nature 389: $835-838$

Sakka A, Gosselin M, Levasseur M, Michaud S, Monfort P, Demers $S$ (1997) Effects of reduced ultraviolet radiation on aqueous concentrations of dimethysulfoniopropionate and dimethylsulfide during a microcosm study in the Lower St. Lawrence Estuary. Mar Ecol Prog Ser 149:227-238

Sanders RW, Porter KG, Bennett SJ, DeBiase AE (1989) Seasonal patterns of bacterivory by flagellates, ciliates, rotifers and cladocerans in a freshwater planktonic community. Limnol Oceanogr 34:673-687

Sanders RW, Caron DA, Berninger UG (1992) Relationships between bacteria and heterotrophic nanoplankton in marine and fresh waters: an inter-ecosystem comparison. Mar Ecol Prog Ser 86:1-14

Scheiner SM, Gurevitch J (1993) Design and analysis of ecological experiments. Chapman \& Hall, New York

Setlow RB (1974) The wavelengths in sunlight effective in producing skin cancer: a theoretical analysis. Proc Natl Acad Sci USA 71:2263-3366

Sherr BF, Sherr EB (1983) Enumeration of heterotrophic microprotozoa by epifluorescence microscopy. Estuar Coast
Shelf Sci 16:1-7

Sherr BF, Sherr EB, Fallon RD (1987) Use of monodispersed, fluorescently labeled bacteria to estimate in situ protozoan bacterivory. Appl Environ Microbiol 53:958-965

Sherr BF, Sherr EB, Pedrós-Alió C (1989) Simultaneous measurement of bacterioplankton production and protozoan bacterivory in estuarine water. Mar Ecol Prog Ser 54: $209-219$

Sherr EB, Sherr BF (1993) Protistan grazing rates via uptake of fluorescently labeled prey. In: Kemp PF, Sherr BF, Sherr EB, Cole JJ (eds) Handbook of methods in aquatic microbial ecology. Lewis Publishers, Boca Raton, FL, p 695-701

Sherr EB, Sherr BF, Berman T, Hadas O (1991) High abundance of picoplanktivorous ciliates during late fall in Lake Kinneret, Israel. Limnol Oceanogr 34:1202-1213

Shiah FK, Ducklow HW (1997) Bacterioplankton growth responses to temperature and chlorophyll variations in estuaries measured by thymidine:leucine incorporation ratio. Aquat Microb Ecol 13:151-159

Šimek K, Bobkova J, Macek M, Nedoma J, Psenner R (1995) Ciliate grazing on picoplankton in a eutrophic reservoir during the summer phytoplankton maximum: a study at the species and community level. Limnol Oceanogr 40 : $1077-1090$

Solórzano L (1969) Determination of ammonia in natural waters by the phenolhypochlorite method. Limnol Oceanogr 14:799-801

Sommaruga R, Oberleiter A, Psenner R (1996) Effect of UV radiation on the bacterivory of a heterotrophic flagellate. Appl Environ Microbiol 62:4395-4400

Stabell T (1996) Ciliate bacterivory in epilimnetic waters. Aquat Microb Ecol 10:265-272

Suttle CA, Chen F (1992) Mechanisms and rates of decay of marine viruses in seawater. Appl Environ Microbiol 58 3721-3729

Tarasick DW, Fioletov VE (1997) The distribution of ozone and ozone depleting substances in the atmosphere and observed changes. In: Wardle DI, Kerr JB, McElroy CT, Francis DR (eds) Ozone science: a Canadian perspective on the changing ozone layer. University of Toronto Press, Toronto

Taylor GT, Iturriaga R, Sullivan CW (1985) Interactions of bactivorous grazers and heterotrophic bacteria with dissolved organic matter. Mar Ecol Prog Ser 23:129-141

Tranvik LJ, Sherr EB, Sherr BF (1993) Uptake and utilization of 'colloidal DOM' by heterotrophic flagellates in seawater. Mar Ecol Prog Ser 92:301-309

Vaqué D, Pace ML (1992) Grazing on bacteria by flagellates and cladocerans in lakes of contrasting food-web structure. J Plankton Res 14:307-321

Villegas PZ (1999) Effets du rayonnement ultraviolet de type $B$ sur une communauté phytoplanctonique de l'estuaire maritime du Saint-Laurent. MSc, Université du Québec a Rimouski

Vincent WF, Roy $S$ (1993) Solar ultraviolet-B radiation and aquatic primary production: damage, protection, and recovery. Environ Rev 1:1-12

Vosjan JH, Döhler G, Nieuwland G (1990) Effect of UV-B irradiance on the ATP content of microorganisms of the Weddell Sea (Antarctica). Neth J Sea Res 25:391-393

Vrba J, Šimek K, Nedoma J, Hartman P (1993) 4-methylumbelliferyl- $\beta$ - $N$-acetylglucosaminide hydrolysis by a highaffinity enzyme, a putative marker of protozoan bacterivory. Appl Environ Microbiol 59:3091-3101

Vrba J, Simek K, Pernthaler J, Psenner R (1996) Evaluation of extracellular, high-affinity $\beta$ - $N$-acetylglucosaminidase measurements from freshwater lakes: an enzyme assay to 
estimate protistan grazing on bacteria and picocyanobacteria. Microb Ecol 32:81-99

Watanabe T, Kitajima C, Fujita S (1983) Nutritional values of live organisms used in Japan for the mass propagation of fish: a review. Aquaculture 34:115-143

Weisse T, Scheffel-Möser U (1991) Uncoupling the microbial loop: growth and grazing loss rates of bacteria and heterotrophic nanoflagellates in the North Atlantic. Mar Ecol Prog Ser 71:195-205

White PA, Kalff J, Rasmussen JB, Gasol JM (1991) The effect of temperature and algal biomass on bacterial production and specific growth rate in freshwater and marine habitats. Microb Ecol 21:99-118

Wickham S, Carstens M (1998) Effects of ultraviolet-B radia-

Editorial responsibility: Fereidoun Rassoulzadegan,

Villefranche-sur-Mer, France tion on two arctic microbial food webs. Aquat Microb Ecol 16:163-171

Wikner J, Rassoulzadegan F, Hagström $\AA$ (1990) Periodic bacterivore activity balances bacterial growth in the marine environment. Limnol Oceanogr 35:313-324

Yentsch CS, Menzel DW (1963) A method for the determination of chlorophyll and phaeophytin by fluorescence. Deep-Sea Res 10:221-231

Zagarese HE, Williamson CE, Vail TL, Olsen O, Queimalinos (1997) Long-term exposure of Boeckella gibbosa (Copepoda, Calanoida) to in situ levels of solar UVB radiation. Freshw Biol 37:99-106

Zar H (1984) Biostatistical analysis. Prentice-Hall, Englewood Cliffs

Submitted; February 8, 1999; Accepted: May 10, 1999

Proofs received from author(s): October 22, 1999 